Tasharruf: Journal Economics and Business of Islam Vol. 4, No. 2 (2019):156-169 Website: http://journal.iain-manado.ac.id/index.php/TJEBI ISSN 2528-0325 (online) ISSN 2528-0317 (print)

\title{
DISTRIBUTION IN ISLAMIC ECONOMIC PERSPECTIVE (CRITICISM TO CAPITALIST)
}

\author{
Telsy Fratama Dewi Samad \\ Institut Agama Islam Negeri Manado \\ Email: telsy_s@ymail.com
}

\begin{abstract}
Distribution is one of the economic topics that is necessary to be discussed, mainly the distribution of wealth because it concerns the effort to achieve prosperity for all levels of society in a country through equitable distribution of wealth. In this article, we will discuss the concept of wealth distribution both from conventional perspective, which is based on capitalist ideology and from the perspective of Islamic economics. As the public understanding about capitalism, it is one of the economic comprehension carried by the Father of Economics "Adam Smith" which emphasizes the individual freedom in managing assets without government intervention. Capitalism has led to injustice and income inequality in the community, causing conflict and creating permanent poverty for the citizens of society. Islam refers the process of distribution of wealth following Islamic principles. Islam prevents the accumulation of wealth in certain small groups and promotes the distribution of wealth to all levels of society. This research is descriptive qualitative based on the study of literature such as books and other literature that are relevant to the problems considered by the author. The purpose of this study is to understand the concept of wealth distribution based on Islamic economic and capitalist economic perspectives. The result of this article concluded that the capitalist wealth distribution system should be replaced by the Islamic economic system that emphasizes the value of freedom as well as the behaviour of human based on religious teachings and the value of justice in ownership.
\end{abstract}

Keywords: Distribution; Capitalist Distribution; Islamic Distribution 
INTRODUCTION

Islam is a way of life as well as universal religion because it embraces all aspects of good life related to economic, social, political and cultural aspects. The fundamental epistemological foundations of the Islamic worldview are thus the Qur'an and the Sunnah. The secondary epistemic medium is the authority of knowledgeable men in Islam used to interpret the tenets of the divine law in the light of the Qur'an and the Sunnah. The oneness of God is conveyed to the multiverses through the Sunnah in reference to the Qur'an. Keeping in view the constructed essentiality of the unified world system through continuous learning, the final realization of all-accumulated ultimate knowledge stock occurs in the Hereafter. Thus, the Hereafter is referred to as the Great Event in the Qur'an (Masudul Alam Choudury, 2011:17). Along with the rapid progress of the study of Islamic economics by using a philosophical approach and so on led to the formation of an Islamic-based economics that is focused to study the economic problems of the people who are imbued with Islamic values.

Islamic economics is not only the expression of sharia which gives the existence of an Islamic system in the midst of the existence of various modern economic systems. But the Islamic economic system is more a complex view of Islam as a result of the expression of Islamic creed with broad nuances and clear targets. The expression of creed gave birth to a form of thought and its application method in the context of society, politics, or the economy (Faruq An Nabaha, 2008:1). The most important field of study in the economy is distribution. Distribution has an important position of microeconomic theory in both the Islamic and capitalist economic system because the discussion in the field of distribution is not only related to mere economic aspects but also social and political aspects so that it becomes a concern for Islamic and conventional economic thinkers to date. (Heri Sudarsono, 2004: 234)

At present the apparent reality is that there has been an injustice and imbalance in the distribution of income and wealth both in developed and developing countries that use the capitalist system as the economic system of their country, thus creating poverty everywhere. Responding to this reality Islam as a universal religion is expected to solve these problems and simultaneously become a country's economic system. This article focuses the discussion on how a brief overview of the capitalist and Islamic economic systems and their respective concepts of distribution (income and wealth distribution). By using the approach of Islamic economic philosophy in order to get a clear picture of the benefits of the Islamic economic system.

\section{RESEARCH METHOD}

Research is a learning process or an attempt to find or to develop and test a truth /knowledge, or to obtain answers to a problem. However, each person can define research differently, but the substance is an attempt to find, develop and test the truth of a knowledge and obtain answers to a problem. The answer to a problem can be either abstract or general answers or concrete and specific answers (Hendri Tanjung, Abrista Devi. 2013:3). The research method is basically a scientific way to obtain data or the results of theoretical discussions that have specific goals and uses. By conducting 


\section{Tasharruf: Journal Economics and Business of Islam Vol. 4, No. 2 (2019):156-169 Website: http://journal.iain-manado.ac.id/index.php/TJEBI ISSN 2528-0325 (online) ISSN 2528-0317 (print)}

research, humans can use the results of their research to then understand, solve or anticipate a problem.

According to Bogdan and Taylor (Metodologi Penelitian Kualitatif, 1996:3) qualitative research methods are research procedures that produce descriptive data in the form of written or spoken words from people and observable behavior. Thus this approach is directed at the setting and individual holistically (whole). So through qualitative research it will gain an understanding of reality through the process of inductive thinking.

Qualitative research has a goal relating to understanding aspects of social life, and methods that generally produce words and not numbers, as data for analysis. In general, qualitative research has two objectives, namely to describe and express as well as to describe and explain (Nana Saodih Sukmadinata, 2011:96). This article uses qualitative research methods that are based on library research. Literature research is carried out by examining libraries that discuss the problem under study (Hendri Tanjung, Abrista Devi. 2013:12). Literature research is conducted by examining books and other literature that are relevant to the problems studied by the author. Based on qualitative methods that emphasize library research, this article seeks to examine the literature related to the concept of distribution in the economic field, both distribution in the capitalist perspective and Islamic economic perspective.

\section{RESULT AND DISCUSSION}

An economic system is a set of principles based on which an economy can run and make decisions about which goods and services to produce, how to produce and exchange them, how should the income from the production be distributed among the factor resources and what shall be the right balance between public sector and private sector and that between free market mechanism and regulation. Broadly speaking, there are following economic systems in the economic literature: Capitalism, Socialism, Mixed Economy, Islamic Economic System. This article focuses on the topic of distribution based on a capitalist perspective and an Islamic perspective.

The concept of Capitalism has significantly changed over past three centuries In $18^{\text {th }}$ century Adam Smith emphasized on self interest, 'invisible hand' and specialization as key elements for capital accumulation. The present day definition emphasises the private ownership of means of production and decision regarding demand, supply, prices (of products and factors of production), distribution and investment to be governed privately under liberal market forces with bare minimal government intervention. However, in practice in all over the world there is some government intervention though the degree of emphasis significantly varies among different counties. For example Sweden has very large share of public sector and government expenditure as compared to United States. Thus in present days the capitalist system is truly a "Mixed Economic System". The degree of control by the private sector (as compared to public sector) has significant impact on distribution of income/ wealth. Sweden society is much more egalitarian then US (with Gini Co- 


\section{Tasharruf: Journal Economics and Business of Islam Vol. 4, No. 2 (2019):156-169 Website: http://journal.iain-manado.ac.id/index.php/TJEBI ISSN 2528-0325 (online) ISSN 2528-0317 (print)}

efficient 0.45 and 0.23 in US (2007) as in Sweden a much larger economic activity is controlled directly or indirectly by the state. In summary, while capitalist system is a widely acceptable and practiced economic system, it is its inherent characteristics to create enormous inequality in distribution of income and wealth. These inequalities would persist and continue to increase unless rectified by strong government intervention. Three 'Ps' i.e. Price (determined by the market forces of Demand and Supply both for goods and factors of production), Profit (earning and maximisation as the sole objective of private investment) and Private Ownership (of productive and other assets) are the key ingredient on which the Capitalist System has been built. (South East Asia Journal of Contemporary Business and Law, Vol. 2, Issue 2 June ISSN 2289-1560, 2013. Dr. S. Ghiasul Haq University Town Peshawar, Pakistan).

Distribution of Wealth based on Conventional and Islamic Approach on Jurnal of Business and Management (Islamic Economic Rasionalism and distribution of Wealth: A Comparative View. IOSR Journal of Bussines and Management. Vol 18, Issue 4, Ver. IV April 2016. Mehwish Darakhshan Zia, Nida Nasir-Ud-Din), it elucidates that Capitalism has remained major tool of remarkable economic growth during past three hundred years and is associated with creating gross inequalities in distribution of income and wealth in the society. The well- known central theme of Communism, forcefully presented by Karl Marx is a reaction to this injustice of the Capitalist Economic System (described as exploitation of labor class by the capitalist). Despite the failure of Communism to provide a better alternate (i.e. state controlled economic system) to ensure equitable distribution of income and wealth in the society, its argument could not be ignored by the Capitalist Societies. As a result almost all over the world a mixed economic system has evolved with different level of emphasis on the role of private and public sector in different countries. Whilst in Islamic Approach, Islamic Economic System provides a midway without compromising the liberty and fundamental human rights. Islamic System discourages earning without effort (as interest) and motivates to work and invest and tax simple accumulation of assets and wealth Islamic system is a divine and human friendly system which has all the best characteristics based on Shariah. It is found that the Islamic theory presents an efficient and friendly way of distribution which may be key to eliminate poverty and facilitates all non active participants of the society in the production of wealth. Further this distribution of wealth establishes a realistic and practical system of economy which enables everyone in the society to fulfil their basic needs fairly and eliminates the concentration of wealth. Many Islamic economists believe that the Islamic norms provide clear guidance in every conceivable economic arena. In an Islamic economy, they believe, disagreements over economic matters will be rare, for individuals will deal with one another fairly and honestly, and conceptions of economic justice will be homogenous. Islamic Economic system actually promotes free market economy but with its regulations. It prevents concentration of wealth. It disapproves increasing money from money i.e. generating interest (riba) rather it advocates trading investments. 


\section{System and Concept of Capitalist Economic Distribution}

The ideology of capitalists emerged and developed in Europe around the 18th Anno Domini which was initiated by The Father of Economics "Adam Smith" through the publication of his second book entitled "An Inquiry into the nature and causes of national wealth" in 1776. Smith developed the ideology of liberal capitalism aimed at gives full freedom to every individual in obtaining material and developing capital maximally. In his second book, Smith discusses many microeconomic issues which are related to human behavior and various other phenomenal theories such as the invisible hand and laizzes faire laizzes passer (let do let past) that represents his thoughts on the absence of government interference in regulating the economy of a country.

Some basic principles of capitalist economy (Afzalur Rahman, 1995: 2)

- Freedom to Own Personal Assets

Every country knows the right to individual freedom to own personal property. Each individual can have his property according to what he wants without obstacles. The individual has full power over his property and is free to use economic resources in the way he wishes.

\section{- Economic Freedom and Free Competition}

Every individual has the right to establish, organize and manage the desired company. Individuals are also entitled to engage in all fields of commerce and get as much profit. The state may not interfere in all economic activities aimed at seeking profits, while such activities are legal according to the regulations of the country.

- Economic Inequality

In the capitalist economic system, capital is a source of production and a source of kebebabsan. Individuals who have greater capital will enjoy more freedom of rights to get perfect results.

Inequality of opportunity makes the gap between the rich get richer and the poor get poorer. As based on the history of the development of economics, it is known that the ideas of classical economic thinkers received criticism from Karl Marx, one of the social and economic figures who carry socialist / communist ideology which is the antithesis of the ideas taught by Adam Smith. According to Karl Marx, in terms of morals, the capitalist system inherits inward inadequacy. This injustice will ultimately lead capitalist society towards economic and social conditions that cannot be sustained. Although there is a recognition that the system based on market mechanism is more efficient, the system is still criticized (Deliarnov, 2014:73)

The basis or value system that forms capitalism is secularism and materialism, in which secularism seeks to isolate knowledge from religion and even ignores the normative or moral dimensions that affect the loss of co-sanctity (played by religion) 


\section{Tasharruf: Journal Economics and Business of Islam Vol. 4, No. 2 (2019):156-169 Website: http://journal.iain-manado.ac.id/index.php/TJEBI ISSN 2528-0325 (online) ISSN 2528-0317 (print)}

which can be used to guarantee acceptance of social economic decisions. Whereas the understanding of materialism tends to encourage people to have a partial understanding of life by assuming matter is everything to him (Hendri Anto, 2003:34). The developing economic system based on capitalist ideology is an implementation of the value of secularism. The capitalist system emphasizes material well-being without spiritual considerations and moral values that are basically the embodiment of secular understanding which generally includes three focus of discussion which they are about the disenchantment of nature, desacarization of politics, deconsecration of value (M. Syukri Ismail, 2007) In a secular view, world issues must be separated from the afterlife. In the field of economics, capitalist ideology emphasizes more on the positive aspects than normative, so that every economic decision taken is highly emphasized to maximize the material without following certain moral values. For the sake of wholeness and continuation of secularism, capitalism in ideology must guarantee and maintain individual freedom, namely freedom of belief, freedom of speech, freedom of ownership and freedom of behavior. Under these values of freedom of ownership, a branch of capitalist economic system of thought is developed, meaning that capitalism has seen that people living in this world are free to regulate their lives and should not be interfered by religion. Religion can only live in churches or mosques.

Thus, all the rules of community life, including in the economic field, are not taken from religion but entirely left to humans, what is seen as providing benefits. With this principle of benefit (naf'iyyah), the good is what gives maximum material benefit to humans and the bad is the opposite. So that happiness in this world is nothing but the fulfillment of all material needs, both material that can be sensed and felt (goods) or that cannot be sensed but can be felt (services).

In connection with the problem of distribution, the capitalist system uses the principle that the resolution of poverty and deprivation in a country by increasing domestic production and giving citizens the freedom to take as much of their production (wealth) as they produce for the country. By solving domestic poverty, the problem of individual poverty is also divided because their attention to production can solve the problem of poverty in them. Then the best solution to solve community problems is to increase production (Abdurrahman Al-Maliki, 2001:12). Thus the economy is only focused on providing tools that satisfy the needs of the community at a macro level by increasing production levels and increasing national income, because with so much national income, income distribution is created by giving freedom of ownership and freedom of business for all individuals. society so that each individual is left free to obtain the amount of wealth that he is able to in accordance with the factors of production that he has and to give his wealth to the heirs in the absolute when they die.

The principle of distribution applied by the capitalist system ultimately impacts the reality that the real rulers are capitalists (owners of capital and conglomerates), therefore it is natural that policies issued by the government always favor the owners of capital or conglomerates and always sacrificing the interests of the people so that there is an imbalance (injustice) distribution of income and income. A phenomenon that occurs due to the practice of capitalist ideology is the gap between the rich and the poor. 


\section{Tasharruf: Journal Economics and Business of Islam Vol. 4, No. 2 (2019):156-169 Website: http://journal.iain-manado.ac.id/index.php/TJEBI ISSN 2528-0325 (online) ISSN 2528-0317 (print)}

While the ability of the rich to pay the price enables them to get whatever they want, the poor get squeezed because their inadequate income does not normally rise in step with prices. Their ability to pay the market price for need-satisfying goods and services thus declines even more, leading to inadequate satisfaction of their needs. This lowers their efficiency and their incomes even further. They get trapped further in the vicious cycle of poverty and deprivation. The greater the income and wealth disparity, the greater the power of the rich to divert resources away from need fulfillment of the poor, if reliance is placed mainly on the price mechanism to allocate resources and to remove the imbalances. This is further exacerbated by the conventional interest-based banking system which diverts the savings of the society mainly to the rich, who have the collateral to offer and who consequently become yet wealthier and more powerful in diverting scarce resources even farther away from need satisfaction (M. Umer Chapra, 1992:343)

\section{System and Concept of Islamic Economic Distribution}

Islamic economics is a social science that studies people's economic problems that are imbued with Islamic values. Dr. Muhammad bin Abdullah al-Arabi defines Islamic economics as a collection of general principles about economics that we take from the Qur'an, sunnah and economic foundation that we build on the basis of these points by considering environmental conditions and time (Abdullah Abdul Husain, 2004:14). So it is very clear that Islamic economics is related and has a close relationship with religion that distinguishes it from the capitalist economic system.

Islamic economics developed gradually as an interdisciplinary field of study that became the study material of the jurists, mufassir, sociologists and politicians, including Abu Yusuf, Yahya bin Umar, Ibn Khaldun and others. The economic concept of these Muslim scholars is rooted in Islamic law which is sourced from the Qur'an and hadith so that it is the result of interpretations of various Islamic teachings that are eternal and universal, containing a number of commands and encouraging its people to use the power of their minds (Adiwarman Azwar Karim, 2004:VI). Islamic economics engaged directly with the key issue of the moral economy, treating it not simply as an ethical enterprise, but also as an economic one. The ambitious task was the construction of the model of an economic order based on distinctively Islamic principles, which would also be successful materially, competing with the apparently all-devouring ethos and apparatus of capitalist enterprise in the twentieth century (Charles Tripp, 2006:103). On two aspects of the ways in which Muslim intellectuals have sought to meet the challenge of capitalism, beyond the earlier efforts to construct an 'Islamic socialism'. The first involves the attempt to devise an 'Islamic economics' as a strategy which would transform and strengthen the power of Islamic societies whilst preserving a distinctively Islamic identity. Acknowledging the power of material factors and thus the success of capitalism in attracting human beings, many of these writers tried to ensure that all economic transactions would be tied to an Islamic ethical system whilst retaining their capacity for productive and material efficiency. A constant theme, therefore, the effort to prevent economic transactions from unleashing a force in human nature which the Islamic revelation was designed to keep in check, partly through excavating the figh for rules on trade, finance, taxation, property, interest and all related economic transactions.

162 | Distribution in Islamic Economic Perspective (Criticism to Capitalist) Telsy Fratama Dewi Samad 


\section{Tasharruf: Journal Economics and Business of Islam Vol. 4, No. 2 (2019):156-169 Website: http://journal.iain-manado.ac.id/index.php/TJEBI ISSN 2528-0325 (online) ISSN 2528-0317 (print)}

(Charles Tripp, 2006:104). The second response to the challenge of capitalism, evident simultaneously in the last decades of the twentieth century, has taken the more practical form of trying to apply some of the principles governing distinctive Islamic economic transactions through the growing practice of Islamic banking. In both areas the theoretical and the practical. There is an impulse to distinguish an Islamic sphere of transactions from a capitalist sphere. If measured by some abstracted and restrictive notion of Islamic authenticity, the endeavour would appear to have had very limited success. However, both areas have provided examples of the ways in which Muslim intellectuals have delineated for Muslims various forms of effective engagement with a world shaped by a particular capitalist modernity, whilst adhering to the spirit and even the letter of the Islamic shari'ah. Whether or not Muslims, variously situated, in terms of location, wealth and other conditions of possibility, will take up these responses, must depend upon a host of other factors, perhaps only a few of them having to do with their identity as Muslims (Charles Tripp, 2006:105).

These Islamic perspectives in consumption, production and distribution can now be viewed to the main assumptions (principles) and instruments of the Islamic economy. The Quran considers the Islamically requisite acts of consumption, production and distribution in relation to the felicity people attain from them, first in this life through acts of righteousness and then, through this, the attainment of supreme felicity in the hereafter. 2 They are therefore treated as acts of worship. On the other hand, Islamically non-requisite acts in these areas are treated as disbelief, and are equated with the habits of the devil. Thus, in the relationships between the main principles of the Islamic economy, felicity is attained through acts of labour and production and distributive equity. The compliance with the sharia in these areas establishes the principle of the unity of God as the creator and sustainer of the universe (the principle of Tawheed and brotherhood). The environment of Islamically-requisite production is established under the institution of cooperation and mudarabah Moderation and Islamically-requisite consumption are established by the instrument of avoidance of waste (israf). The instrument is equally applicable to production. Distributive equity is established by the mandatory Islamic wealth tax (zakah) (Masudul Alam Choudury, 1992:42).

The Islamic view of capitalism which says that wealth is everything is an invalid understanding. That is because, besides having a material dimension, humans also have a non-material (spiritual) dimension. In essence, it is very clear that materialism only equips human life with wealth, enjoyment, and physical pleasure by ignoring the spiritual dimension. In Islamic perspective, this world is a place to compile good fortune for eternal life in the hereafter. the purpose of human life is to achieve falah, which is holistic well-being both in the world and the hereafter, so that during his lifetime, humans in doing something must always pay attention to the good that is not only felt in the world, but can also have an impact on giving goodness in the afterlife.

In Islamic economy, both dimensions of material and non-material are covered therein as reflected by its value based values, namely godliness, balance, free will and responsibility (Syed Nawab Heidar Naqvy, 1981:21). Diversity serves to distinguish the khaliq and its creatures followed by the unconditional submission of each being to His will and to provide a definite perspective that guarantees the process of seeking the truth 
of humanity that is achieved through the guidance of Allah. Balance is a horizontal dimension of Islam that in a more practical perspective includes physical, spiritual, nonmaterial, individual and social. Whereas the meaning of the free will here is the freedom framed by monotheism, it means that humans are not free but are bound by the restrictions given by God. And responsibility is the logical consequence of the existence of freedom that not only encompasses everything in the world and the hereafter but also the surrounding environment (Hendri Anto, 2003:34)

As the basic principles of the Islamic economic system (Afzalur Rahman, 1995:8-10):

- Freedom

IndividualIndividuals have the right to freedom of opinion or make decisions as deemed necessary in an Islamic state.

- The right of property

Islam recognizes the right of individuals to own property. Nevertheless he provides certain restrictions so that freedom does not harm the interests of the general public.

- Economic inequalities within reasonable limits

Islam recognizes economic inequalities among individuals but does not allow them to become wider, Islam tries to make these differences within reasonable, fair, and not excessive limits.

- Social Equality

Islamic does not encourage economic equality but it supports and promotes social equality so that to the extent that the country's wealth is not only enjoyed by a certain group of people.

- Social Security

Every individual has the right to live in an Islamic state, and every citizen is guaranteed to obtain their basic needs, is the main duty of an Islamic state to guarantee every citizen and fulfill his needs in accordance with the principle of "the right to life".

- Widespread Distribution of Wealth

Islam prevents the accumulation of wealth in certain small groups of people and promotes the distribution of wealth to all walks of life. 
- Prohibition of Piling up wealth

The Islamic economic system prohibits individuals from accumulating excessive wealth and taking the steps necessary to prevent such misconduct from happening in the state.

- Prohibition of Anti-social organizations

The Islamic economic system prohibits all destructive and antisocial practices in society, such as gambling, drinking alcohol, accumulation of assets, the black market, and so on.

- The welfare of Individuals and The Community

Islami crecognizes the welfare of individuals and the social welfare of communities which complement one another rather than competing against one another.

Related to distribution theory, Islam prevents the accumulation of wealth in certain small groups and promotes the distribution of wealth to all level of society. From the various descriptions of Islamic economic principles above, Islamic economic principles that are built with Islamic moral values declare the interests of equitable distribution of income (Mustafa Edwin Nasution, 2007:146), but capitalist economy carried out by giving freedom of ownership and freedom of effort for all individual societies, so that each individual society is free to obtain the amount of wealth that it is capable of and in accordance with its factors of production without regard to whether the distribution is equally felt by all individuals of the community or only for some (Abdurrahman Al-Maliki, 2001:14). The theory applied by the capitalist system is inaccurate and in the view of Islamic economics is mistaken because if the theory is applied it has implications for the accumulation of wealth on some parties and the incapacity on the other. As the word of Allah Most High:

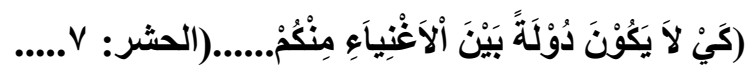

"So that treasure does not circulate to only rich people among you.." (Q.S AlHasyr:7)

In this verse illustrates to reduce the inequality of income and wealth in society. If there is a striking economic difference between the rich and the poor, it will result in mutual hatred, which in turn gives rise to hostility and division in society.

And the hadith which explains the importance of distribution by Prophet Muhammad:

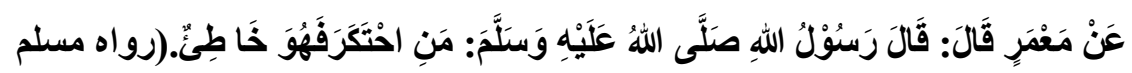

"From the Ma'mar he said, Allah's Messenger (may peace be upon him) said: Whoever hoards the goods, then he is guilty." (HR. Muslim) 


\section{Tasharruf: Journal Economics and Business of Islam Vol. 4, No. 2 (2019):156-169 Website: http://journal.iain-manado.ac.id/index.php/TJEBI ISSN 2528-0325 (online) ISSN 2528-0317 (print)}

The Prophet Muhammad also showed the result of the unequal distribution of wealth in society, based on the Prophet's words:

"On one hand excess wealth can endanger the faith and morals of Muslims, and on the other hand, poverty can drag them to kufr" (Afzalur Rahman, 1995:35)

In other words, economic inequality is the base of crime and chaos in society which ultimately leads to destruction.

The most substantial aspect of building an Islamic economy is related to its aim to implement the values of justice and balance in terms of allocation of potential resources for the community. A justice framework also allows each person to have the opportunity, control, and benefits of the allocation of development that takes place proportionally (Euis Amalia, 2009:116).

The concept of justice in the view of a prominent scholar Ibn Taimiyyah in one of his quotes, he describes: He had seen the agony of the poor classes and the exploitation by the ruling class. So deeply did this impress his dynamic and conscientious spirit that he could not keep silent. What also inspired him was that Islam as a religion does concern itself with economic problems and holds certain fundamental principles in regard to them (Abdul Azim Islahi, 1996:70). Ibn Taimlyah emphasized that every person must be assured a minimum standard of living sufficient for him to fulfil his obligations to the Almighty and to his brethren. Equally, he emphasized justice; that is, he sought to point out the responsibilities of the individual as well as the state, so that both could co-operate with each other and neither was abused. According to him, justice is a value recognized by all nations. He says: 'All people agreed that the consequences of injustice are gloomy, and the fruit of justice is admirable.

Lebih lanjut, M. Anas Zarqa put forward several principles of distribution in Islamic economics, namely: 1) meeting the needs of all creatures; 2) has a positive effect on the giver himself, for example zakat, besides being able to clean oneself andproperty muzakkialso increases faith and fosters the habit of sharing with others; 3) create goodness among all people between rich and poor; 4) reduce the income and wealth gap; 5) better utilization of natural resources and fixed assets; 6) giving hope to others through giving.

The Islamic economic system requires that in terms of distribution must be based on two joints, namely the joints of freedom and fairness of ownership (Yusuf Qardhawi, 2001:31). Freedom here is freedom of action in the frame of religious values and justice, unlike the understanding of capitalists who declare it as an act of freeing humans to act and act without interference from any party, but as a balance between the individual and his material and spiritual elements. The balance between individuals and society as well as between a community and other communities. This justice in distribution is reflected in the prohibition in the Qur'an so that assets are not allowed to become merchandise that only circulates among the rich, but are expected to contribute to the welfare of society as a whole (Zainuddin Ahmad, 1998:7). 
In capitalist economic system, poverty can be solved by increasing the level of production and national income is a theory that cannot be proven. The fact that poverty occurs is a result of the economic system of capital which then cause the injustice in the distribution of wealth. Poverty occurs not because of the unavailability of food ingredients, but because of the unequal distribution.

This injustice is also reflected in the use of technical advances achieved by science that can only be enjoyed by relatively wealthy people, whose income exceeds the income limit for daily living while those who live just have a bit to consume everyday are forced to continue to suffer eternal poverty, for only by reducing consumption today can provide ever-increasing yields for tomorrow, and we cannot do so unless our current income leaves little more than the necessities of daily life.

The Islamic economic system is inseparable from the entire system of Islamic teachings in an integral and comprehensive manner. So that the basic values of Islamic economics refer to the essence of Islamic teachings. The compatibility of the system with human nature is not abandoned. This harmony has an effect on the absence of conflicts in implementation. Controlled economic freedom is a characteristic and principle of Islamic economics. Individual freedom has an element of production in running the wheels of the economy is an important part with no harm to the collective interest (Tim Penulis MSI UII, 2008:31).

Islam is perhaps the only religion that gives a high and positive value to lawful economic activity. The gain from economic activity is considered a 'bounty' from Allah. The following verses of the Qur'an express this idea succinctly: (Abdul Azim Islahi, 1996:151)

- So they returned with grace and bounty from Allah, and no harm touched them. They followed the good pleasure of Allah, and Allah is of infinite bounty

- And let not those who possess bounty and ease among you swear not to give to the near of kin and to the needy and to fugitives for the cause of Allah

- And when the prayer is ended, then disperse in the land and seek of Allah's bounty, and remember Allah much, that ye may be successful

- He knows that there are sick folk among you, while others travel in the land in search of Allah's bounty

The Islamic economic system is very protective of the necessity of every citizen both rich and poor by giving moral responsibility to the rich as well as paying attention to the poor. Islam recognizes the system of private property in a limited way, any business that leads to the accumulation of improper wealth in the hands of few people will be condemned. The Qur'an states that the rich should spend a portion of their fortune for the welfare of the community, in the way of zakat, sadaqaah, grants, and so on, because wealth must be well spread. 
Islamisation implies a serious implementation of the Islamic strategy to raise the spiritual as well as the material well-being of all people and to establish socio-economic justice, which is the central objective of the Islamic message. On the spiritual side, the peace of mind that is indispensable to inner happiness cannot be attained except by increasing the nearness of the human being to his Creator, which Islam is capable of bringing about but secularism does not even aspire to. On the material side, Islamisation demands the allocation and distribution of all resources, a trust from God, in such an efficient and equitable manner that the maqasid are realized and the hayat tayyibah is made possible for all. This necessitates the balanced and effective use of all the constituent elements of the Islamic strategy to hold aggregate claims within the bounds of resource availability and goal-realization. Islamisation does not thus mean an absence of liberalization. It does, however, mean a different kind of liberalization, one in which all public and private sector economic decisions are first passed through the filter of moral values before they are made subject to the discipline of the market (M. Umer Chapra, 1992:347-348).

\section{CONCLUSION}

The distribution system in the capitalist economy encourages injustice and income inequality in society, and causes conflict and creates permanent poverty for the citizens. Whereas Al-Qur'an and al-Hadith and other sources of Islamic law are both spirits and value references that bring economic justice by setting material and immaterial balance. Humans in the Islamic economy are positioned as the holder of the mandate for the balance, so that economic behaviour provides individual freedom and social responsibility. With this depravity the capitalist ideology should be abandoned and replaced with an Islamic economic system that emphasizes the value of freedom based on religious teachings and the value of justice in ownership.

\section{REFERENCES}

Ahmad, Zainuddin (1998). Al-Qur'an: Kemiskinan dan Pemerataan Pendapatan. Yogyakarta: Dana Bhakti Prima Yasa.

Al-Maliki, Abdurrahman (2001). Politik Ekonomi Islam. Bangil: Al-Izzah.

Amalia, Euis (2009). Keadilan Distributif dalam Ekonomi Islam. Jakarta: Rajawali Press.

An-Nabaha, Faruq. Sistem Ekonomi Islam-Pilihan Setelah Kegagalan Sistem Kapitalis dan Sosialis. 2008. Yogyakarta: UII Press.

Anto, Hendrie (2003). Pengantar Ekonomika Mikro Islami. Yogyakarta: Ekonisia UII.

At-Tariqi, Abdullah Abdul Husain (2004) Ekonomi Islam - Prinsip, Dasar dan Tujuan. Yogyakarta: Magistra Insania Press

168 | Distribution in Islamic Economic Perspective (Criticism to Capitalist) Telsy Fratama Dewi Samad 
Tasharruf: Journal Economics and Business of Islam Vol. 4, No. 2 (2019):156-169

Website: http://journal.iain-manado.ac.id/index.php/TJEBI

ISSN 2528-0325 (online) ISSN 2528-0317 (print)

Bogdan dan Taylor (1996). Metodologi Penelitian Kualitatif. Bandung: PT. Remaja Rosda Karya

Chapra, M. Umer (1992). Islam and The Economic Challenge. USA: The International Institute of Islamic Thought

Choudury, Masudul Alam (1992). Principle of Islamic Political Economy: A Methodological Inquiry. United Kingdom: The MacMillan Press

Deliarnov (2014). Perkembangan Pemikiran Ekonomi. Jakarta: Rajawali Press

Islahi, Abdul Azim (1996). Economic Concept of Ibn Taimiyyah. United Kingdom: The Islamic Foundation

Ismail, M. Syukri (2007). Kritik Terhadap Sekularisme (Pandangan Yusuf Qardhawi). Ponorogo: Cetre for Islamic and Occidental Study

Karim, Adiwarman Azwar (2004). Sejarah Pemikiran Ekonomi Islam. Jakarta: Rajawali Pers

Nasution, Mustafa Edwin, Dkk. (2007) Pengenalan Eksklusif Ekonomi Islam. Jakarta: Kencana

Naqvi, Syed Nawab Haider (1981). Ethics and Economics An Islamic Synthesis. London: The Islamic Foundation

Rahman, Afzalur (1995). Doktrin Ekonomi Islam Jilid 1. (Jakarta: Dana Bhakti Wakaf)

Sudarsono, Heri (2004) Konsep Ekonomi Islam - Suatu Pengantar. Yogyakarta: Ekonisia UII

Sukmadinata, Nana Saodih (2011). Metode Penelitian Pendidikan. Bandung: Remaja Rosda Karya

Tanjung, Hendri, dkk. (2013). Metodologi Penelitian Ekonomi Islam. Jakarta: Gramata Publishing

Tim Penulis MSI (2008). Menjawab Keraguan Berekonomi Syariah. Yogyakarta: MSI UII bekerjasama dengan Safiria Insania Press

Trip, Charles. (2006). Islam and The Moral Economy: The Challenge of Capitalism. United Kingdom: Cambridge University Press

Qardhawi, Yusuf (2001). Norma dan Etika Ekonomi Islam. 2001. (Jakarta: Gema Insani Press). 